Article

\title{
Analysis of Free and Combined Chlorine Concentrations in Swimming Pool Water and an Attempt to Determine a Reliable Water Sampling Point
}

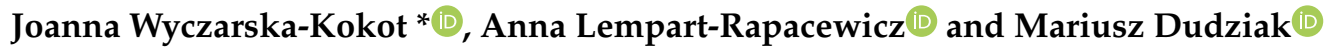 \\ Department of Water and Wastewater Engineering, Faculty of Energy and Environmental Engineering, Silesian \\ University of Technology, Konarskiego 18, 44-100 Gliwice, Poland; anna.lempart@polsl.pl (A.L.-R.); \\ mariusz.dudziak@polsl.pl (M.D.) \\ * Correspondence: joanna.wyczarska-kokot@polsl.pl; Tel.: +48-32-237-16-98
}

Received: 17 December 2019; Accepted: 19 January 2020; Published: 21 January 2020

check for updates

\begin{abstract}
The analysis of free chlorine concentrations in swimming pool water makes it possible to assess the antiseptic effect of the disinfectant. The concentration of combined chlorine determines the comfort of swimming and indicates if there is a threat from DBP (disinfection by-products). The distribution of free and combined chlorine concentration was analyzed in four basins differing in seasonality of use and in the applied water flow systems. After considering the distribution of free and combined chlorine content in characteristic points of pools, an attempt was made to determine the most reliable point for assessing the quality of water and its suitability for swimming. Such searches should aim to identify the places with the worst water quality. The most uniform distribution of the concentrations of both free and combined chlorine was observed at the middle point of swimming pools, while at points near the corners and walls of swimming pools a varied distribution was observed. Such a control strategy, based on the least favorable test results at a point considered as characteristic, would make it possible to verify the parameters of the swimming pool water treatment system and thus minimize the risk to swimmers' health.
\end{abstract}

Keywords: free chlorine concentration; combined chlorine concentration; reliable sampling points; swimmers' health; pool hydraulic system; control strategy

\section{Introduction}

The operation of modern swimming pool systems is based on closed water circulation with active overflow and treatment in the installation, as presented in Figure 1. In public swimming pools, the obligatory process of swimming pool water treatment is the disinfection with chlorine compounds due to the antiseptic effect of so-called "free chlorine", and its ability to oxidize organic and inorganic compounds. As a side effect of this method, disinfection by-products (DBP) are formed [1-5].

The amount and type of DBP in swimming pool water depends on the treatment technology, the number of swimmers and the intensity of swimming, the pool's hydraulic system, the number of water exchanges during the day, swimming pool construction (capacity, water surface area) and the type of pollution introduced into the water together with the bathers [6-10]. Most DBPs are harmful to health [11-13].

The indicator of the DBP content in swimming pool water is combined chlorine [4,14-16]. These two parameters (the content of free and combined chlorine) are the basic parameters of swimming pool water quality, determining the level of health-safe bathing [1,17-20]. 


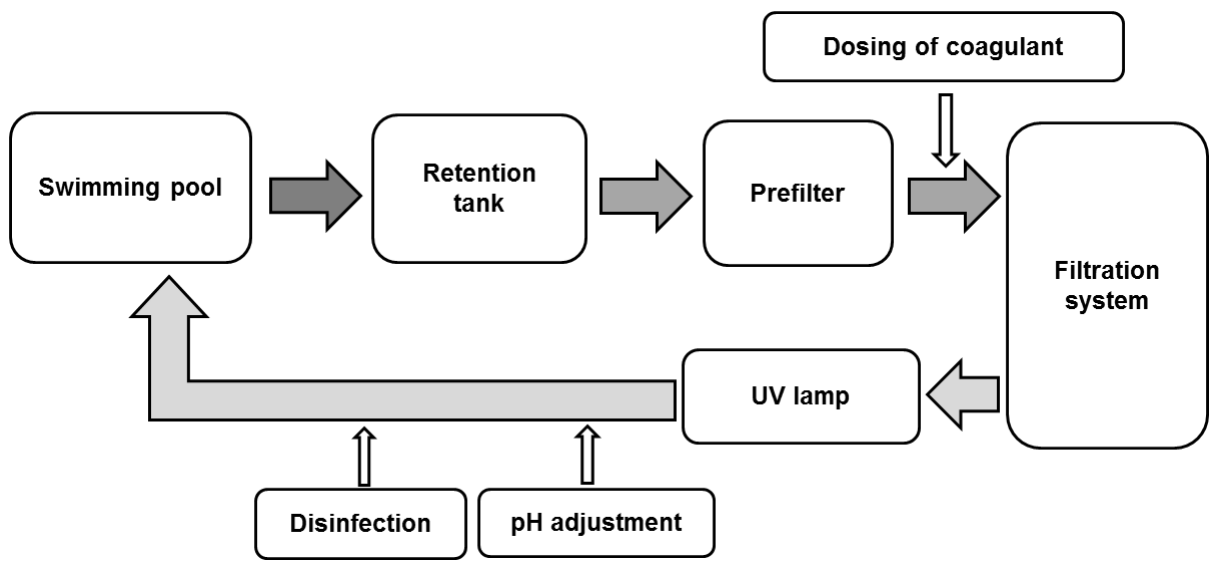

Figure 1. Diagram of typical water treatment installation in swimming pools.

To ensure the health safety of swimmers, it is necessary to achieve a very good level of mixing water in a pool basin with treated water supplied with disinfectants. Water inlets should be located in a pool basin so that the treated water containing disinfectants quickly reaches all places of the basin. At the same time, the shortest route should be prepared to let out the polluted water. Overflow gutters and nozzles are used for this. Depending on the location of the nozzles, the water flow in the pool may be vertical or horizontal. In the case of a vertical hydraulic system, water is supplied to the pool through a distribution system placed on the bottom of the pool. In the horizontal flow, treated water is introduced through the holes in the opposite walls of the pool. In newly built pools, it is recommended that the long walls of the pool be used for this purpose. Older pools use the water inlet in the short walls. In these solutions, on the opposite side of the inlet, a certain volume of water is released from the bottom of the basin using the pool water pumps [10,21,22].

The pool water treatment and disinfection fulfills its task only if the hydraulic system cooperates with the pool basin geometry. Water flowing through the pool can create zones that are not involved in circulation. In these so-called "dead zones", the degree of mixing the disinfectant with water can be different. In consequence, the effectiveness of microorganisms' deactivation and the health effects on bathers may be different. Even the best-designed pool water treatment system, with multi-stage and modern disinfection, will not protect bathers' health if the flow of water through the pool leads to the creation of areas where microorganisms (including pathogens) may develop or even survive. It should be emphasized, however, that in order to prevent excessive introduction of pathogens into the pool water, it is necessary that users observe the swimming pool hygiene rules (showering before entering the pool hall, using toilets, etc.) and that they are educated on how to use swimming pools [20,23-25].

The results of the pool water quality analysis largely depend on the place where the water sample is taken for testing. The inconsistency in water quality at different points of the basin makes it difficult to give an unambiguous, final assessment of the pool water quality (suitable for bathing or not). Rapid assessment of water quality is also very important, and this, according to the authors' knowledge and experience, could be initially determined on the basis of in situ tests of free and combined chlorine. Such a control strategy, based on the least favorable test results at a point considered to be characteristic, would make it possible to verify the parameters of the swimming pool water treatment system and thus minimize the risk to swimmers' health.

After the analysis of the chlorine content in various points of swimming pool basins and supplementary parameters, the authors made an attempt to find reliable sampling points for assessing the quality of pool water in terms of health safety for swimmers. Such searches should aim to identify the places with the worst water quality. It is very likely that if the water adheres to the quality requirements in places considered to be the most vulnerable to higher concentration of pollutants, it will most certainly meet the requirements in places where such concentrations will not occur or where it will not be so high $[10,18,21]$. 
The main aim of the research was to determine the concentration of the free and combined chlorine in various points of different swimming pool basins. An attempt was made to find the reliable sampling points for a quick assessment of the suitability of water for bathing in public pools.

\section{Materials and Methods}

\subsection{Characteristics of Research Objects}

Four different public swimming pools (listed in Table 1) located in Poland were selected for the study. Their function and water treatment scheme are similar. The main differences are: hydraulic system (vertical in SP1 and SP2, horizontal with nozzles in the long pool wall in SP3 and horizontal with nozzles in the short pool wall in SP4), type of basin (SP2 is outdoor, while the others are indoor), filter type (vacuum, open with diatomaceous earth in SP2 and pressure, closed with sand-anthracite bed in others) and disinfection method (sodium hypochlorite + UV lamp in SP 1 and SP2, only sodium hypochlorite in SP3 and SP4). Because the kind of compounds that are formed in the water subjected to chemical disinfection is influenced by the type of disinfectant used, the pools selected for the study use the same disinfectant (14.5\% stabilized sodium hypochlorite solution).

Table 1. The characteristics of tested swimming pools.

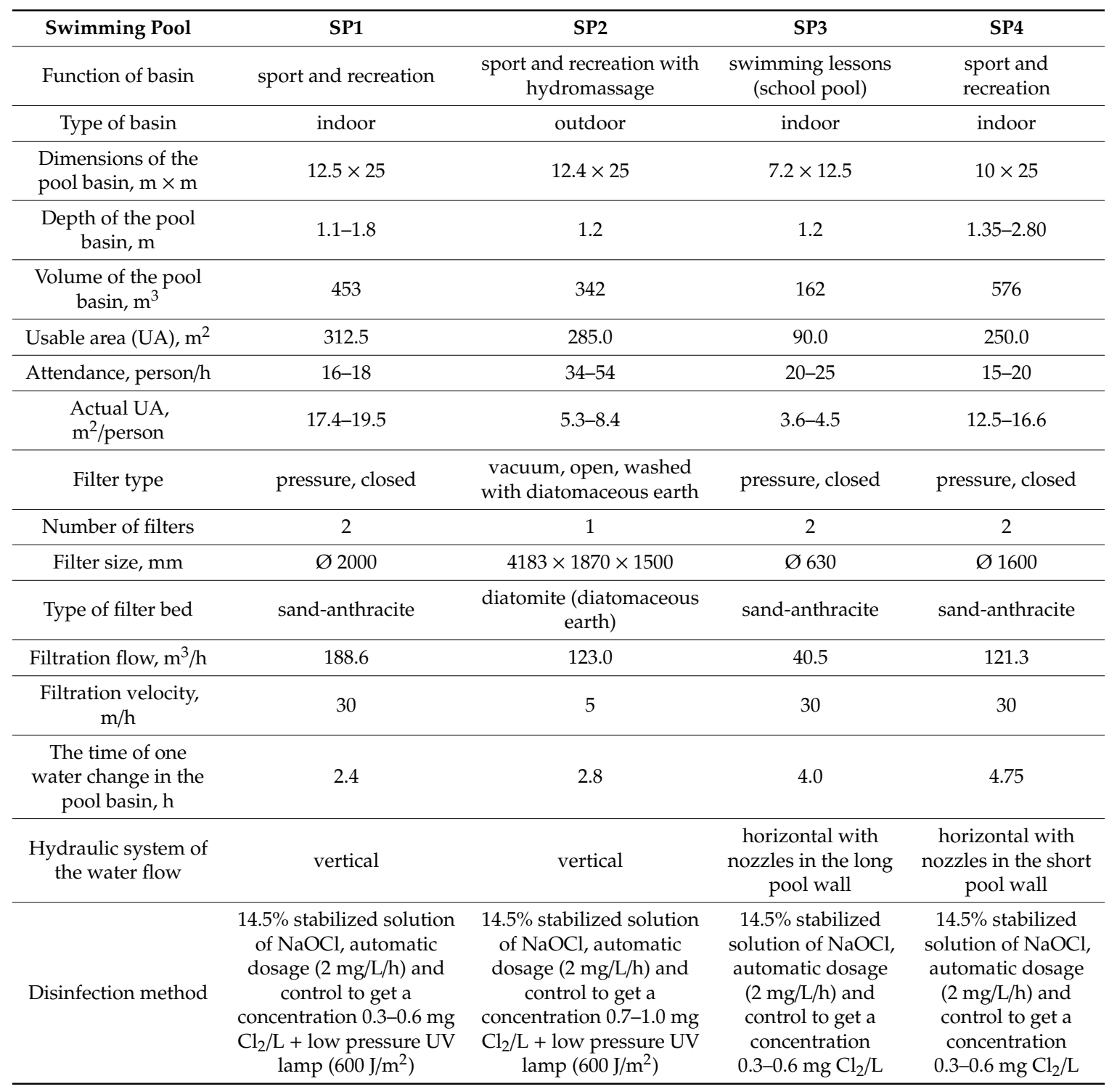




\subsection{Water Samples}

Water samples for analysis were collected early in the morning before the swimming pools' opening time in order to avoid swimmers' impact on the obtained results. In each of the basins, based on the results of model tests on hydraulic systems in swimming pools and the author's results of previous research in this area, points located near the walls, in corners, on shallower and deeper side and in the central part of the pool were selected as characteristic (Figure 2) [26-28]. Samples from each pool had been taken for five days over a one-week period. Sampling took place in accordance with the guidelines of the unified standard (PN-EN ISO 5667-3:2013-05), and they were taken from a depth of about $30 \mathrm{~cm}$ below the water surface.

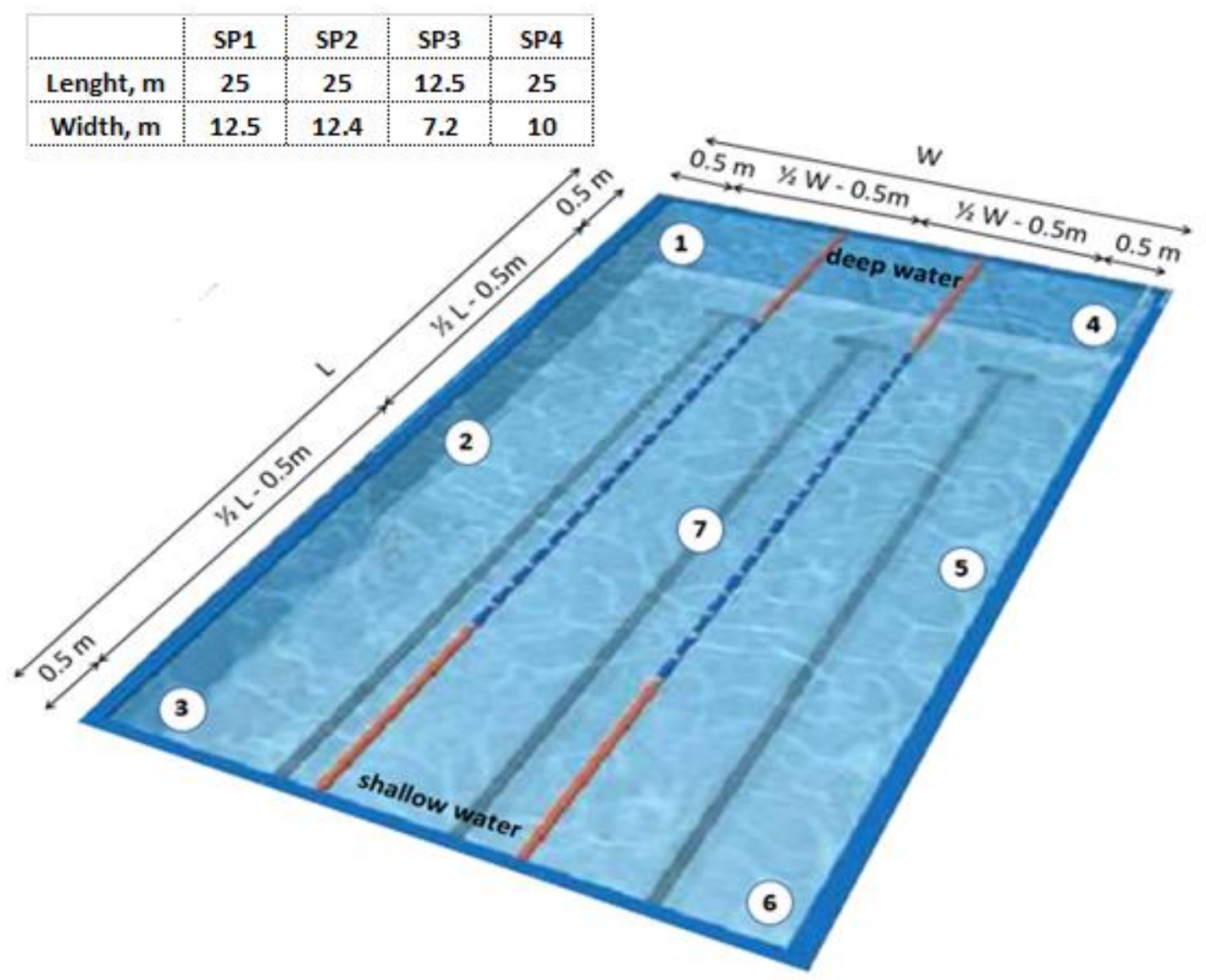

Figure 2. Location of sampling points in tested swimming pools.

\subsection{Chlorine and Additional Parameters Measurement}

The concentration of free chlorine and total chlorine was determined in situ for each water sample, using the colorimetric method performed with the use of portable Pocket Colorimeter TM II by Hach ${ }^{\circledR}$ (Loveland, CO, United States). The concentration of combined chlorine was calculated as the difference between total and free chlorine concentration.

To access the overall quality of swimming pool water, additional parameters were determined. They included redox potential (sensION meter + MM150 DL, Hach ${ }^{\circledR}$, Loveland, United States), turbidity (TN 100 turbidity meter, Eutech ${ }^{\circledR}$, Singapore), nitrate content, chemical oxygen demand-COD and total trihalomethanes-THM (DR 5000 spectrophotometer; Hach ${ }^{\circledR}$, Loveland, United States), total organic carbon-TOC (TOC-L total organic carbon analyzer; Shimadzu ${ }^{\circledR}$, Kioto, Japan), number of colony forming units (cfu), Pseudomonas aeruginosa (membrane filtration method according to PN-EN ISO 16266:2009) and the Escherichia coli cfu number (membrane filtration method according to PN-EN ISO 9308-1:2014-12/A1:2017-04), and total number of mesophile microorganisms (PN-EN ISO 6222:2004). 
The analysis of the research results was based on the Microsoft Excel data analysis package. Each sample was analyzed three times and the presented results are the average values of these repetitions.

\section{Results and Discussion}

In all tested basins, there was a large variation in the chlorine content, depending on both the point of sampling and the day of measurement. The statistical analyzes were performed in MS Excel. The difference test and median test between mean values were carried out at the assumed level of significance $\alpha=0.05$. The distribution of free and combined chlorine in the selected points of the basins is shown in Figures 3 and 4, respectively. The presented results are the average values of the measurements from 5 days. It can be observed that the average variability (measured as the standard deviation of free chlorine content, SD) due to the point of sampling in SP1 (SD = 0.02) and SP2 (SD = $0.03)$ was lower than in SP3 $(\mathrm{SD}=0.07)$ and SP4 $(\mathrm{SD}=0.08)$.

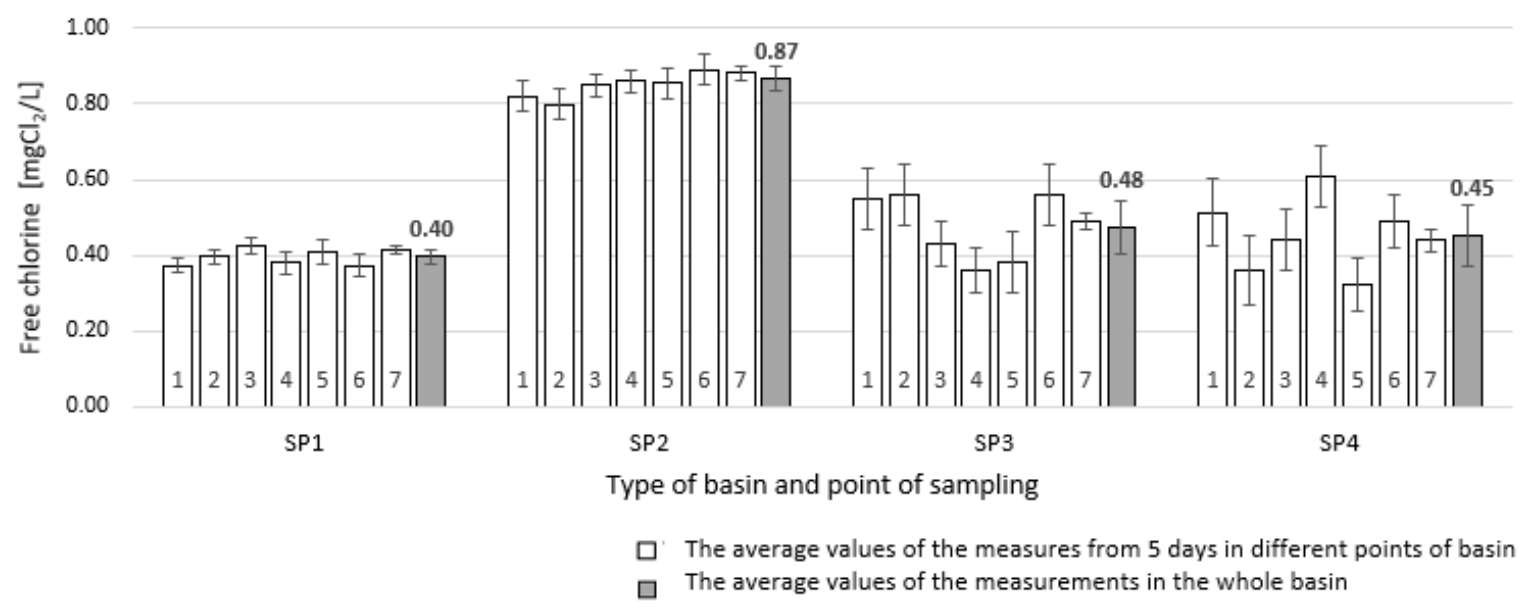

Figure 3. The distribution of free chlorine in the selected points of the basins.

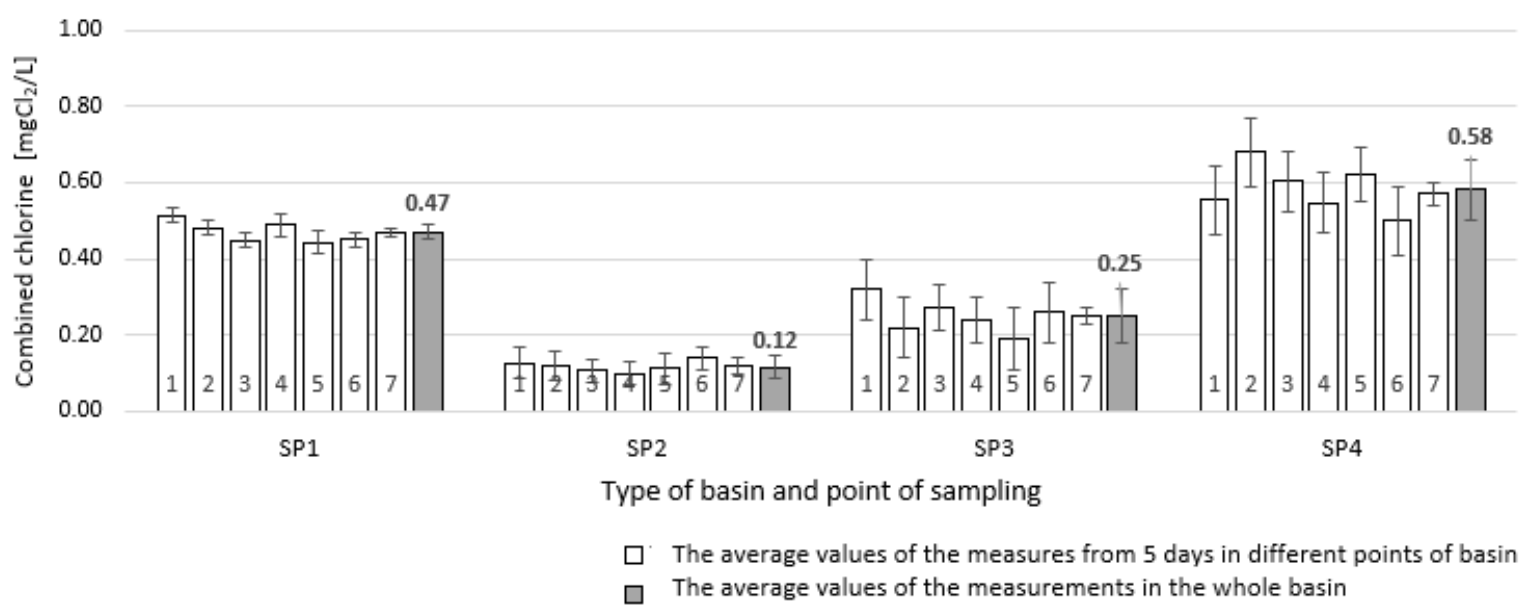

Figure 4. The distribution of combined chlorine in the selected points of the basins.

That indicates a better mixing of water in the vertical hydraulic system of water flow (SP1 and SP2) than in the horizontal system (SP3 and SP4). In every case, chlorine content in the central part of the pool (point 7) was the most similar to the average value for the whole basin, which indicates that mixing of water is best in the central part of the pool. 
Each sample was analyzed 3 times. The deviations did not exceed 5\%, which indicates a high repeatability of results. The results of the research were compared with the recommendations of the regulation on the requirements for water in swimming pools $[1,29,30]$.

Figure 5 presents the correlation between the content of free chlorine and the combined chlorine in the tested pools. The calculated $r$-Person correlation coefficient was equal to 0.883 , which means that the correlation between the content of free and combined chlorine is significant. The formula of the regression equation with the coefficient of determination is presented in Figure 5.

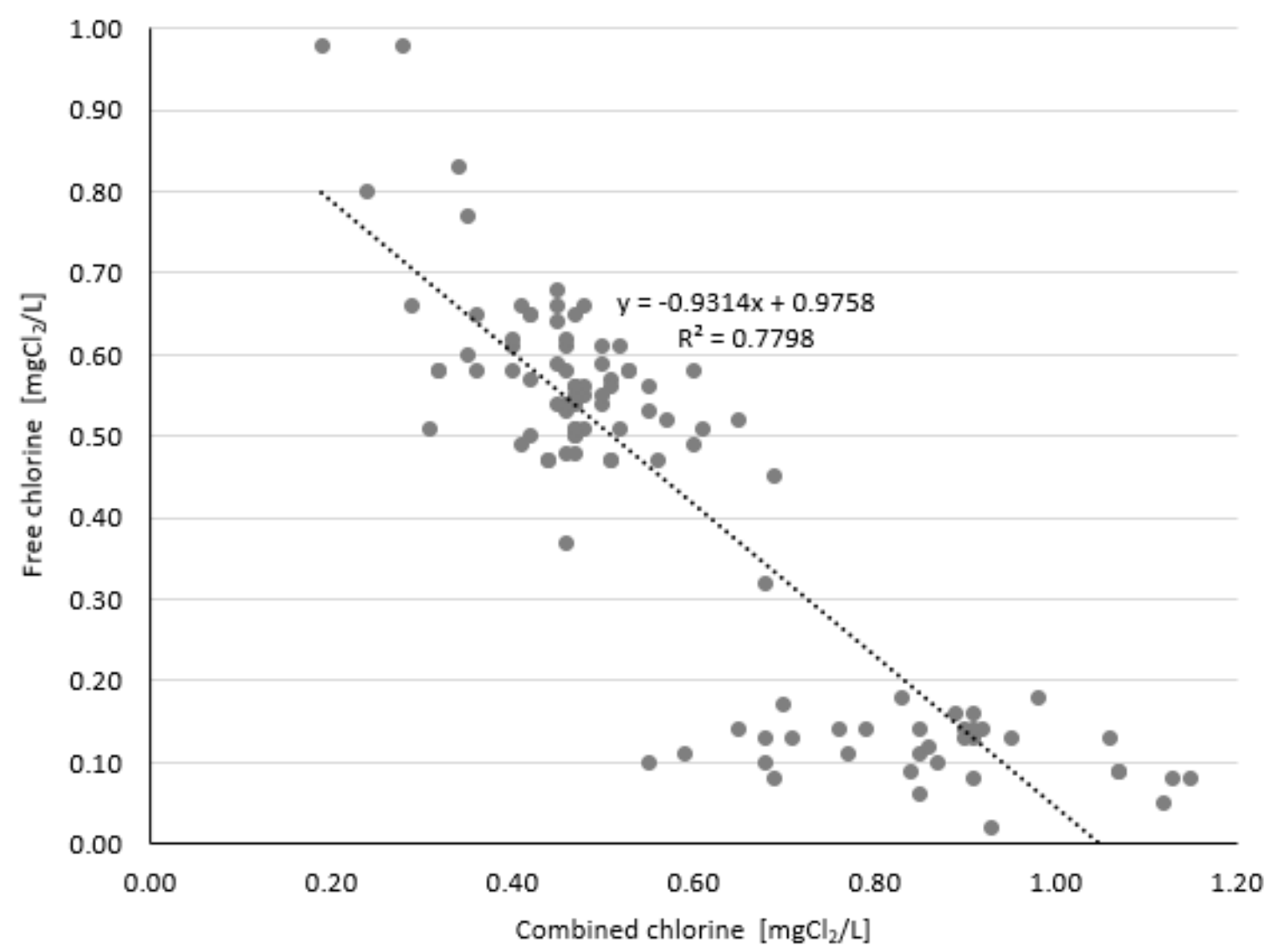

Figure 5. The correlation between the content of free and combined chlorine in tested pools.

The daily variability of free and combined chlorine content is presented in Figures 6 and 7, respectively. The presented results are the average values of the measurements from different points of sampling, collected every day of the study. The average free chlorine content meets the requirements (0.3-0.6 $\mathrm{mg} \mathrm{Cl}_{2} / \mathrm{L}$ ) in the indoor pools (SP1, SP3 and SP4), but exceeds them considerably in the outdoor pool (SP2). The specificity of the outdoor swimming pool compared to the indoor swimming pools (the greater load of swimmers, the more intense sunlight on the surface of the water, greater exposure to contaminants from the pool beach and cosmetics) resulted in higher doses of disinfectant, used in order to limit the growth of unwanted bacteria. On the other hand, average concentrations of combined chlorine in indoor pools ranged from $0.23 \mathrm{mg} \mathrm{Cl} / \mathrm{L}$ up to $0.62 \mathrm{mg} \mathrm{Cl} / \mathrm{L}$ and repeatedly exceeded the limit value, i.e., $0.3 \mathrm{mg} \mathrm{Cl}_{2} / \mathrm{L}$. Meanwhile, in SP2, the combined chlorine concentrations were very small, from $0.10 \mathrm{mg} \mathrm{Cl}_{2} / \mathrm{L}$ to $0.13 \mathrm{mg} \mathrm{Cl}_{2} / \mathrm{L}$. Such a difference in the content of combined chlorine (chloramines) was the effect of using different doses of disinfectant (Table 1). 


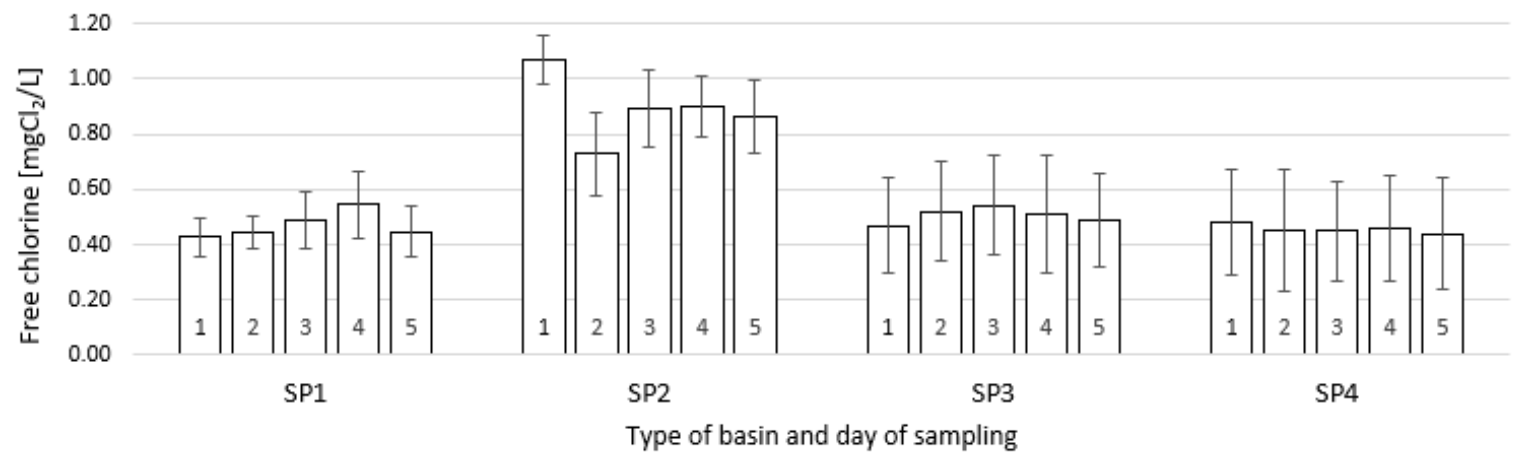

Figure 6. The daily variability of free chlorine in different swimming pools.

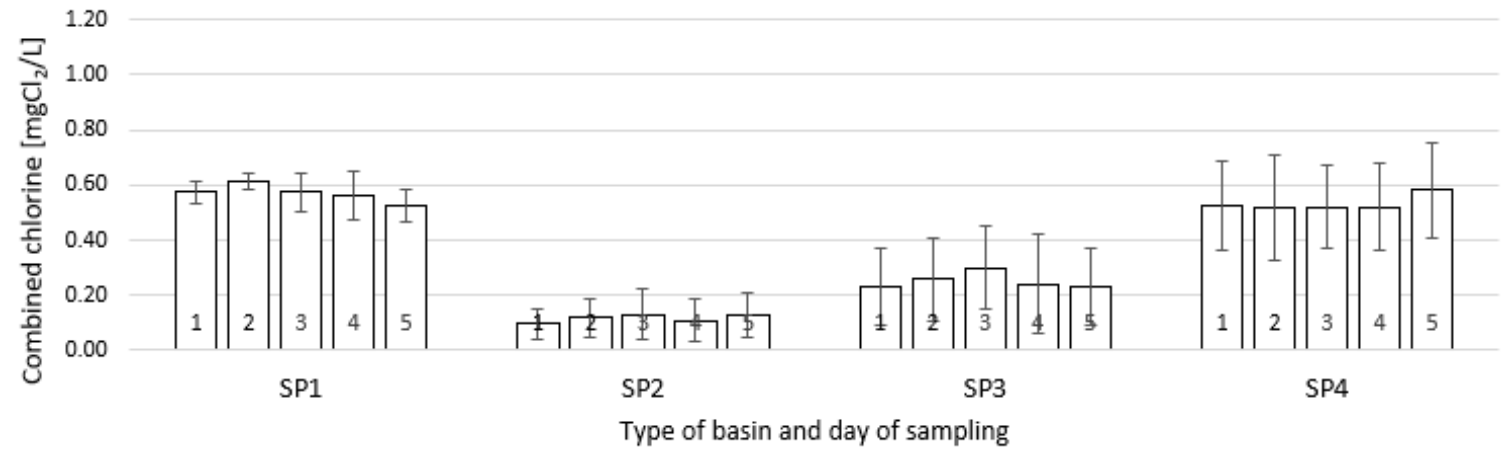

Figure 7. The daily variability of combined chlorine in different swimming pools.

The strength of the dosed disinfectant solution is calculated based on the pool capacity, circulation speed and maximum bath load. The chlorine dosing system should be adjusted so that the concentration of free chlorine is $0.7-1.0 \mathrm{mg} \mathrm{Cl}_{2} / \mathrm{L}$ in outdoor pools, and $0.3-0.6 \mathrm{mg} \mathrm{Cl}_{2} / \mathrm{L}$ in indoor pools. To maintain a stable level of a disinfectant, it is necessary to combine effective distribution and automatic control system with dosing pumps of the right size and a disinfectant of known strength $(14.5 \% \mathrm{NaOCl}$ was used for the tested pools).

To avoid problems associated with maintaining the appropriate quality of pool water, including adhering to the required concentrations of free and combined chlorine, pool facility managers should in particular: frequently monitor and adjust $\mathrm{pH}$ values, redox potential and levels of disinfectants to the applicable requirements, regularly conduct microbiological tests, effectively clean the walls of swimming pools and filtration devices, including periodic disinfection of filter beds (in which microorganisms can form a biological membrane), control the number of pool users, encourage them to comply with the rules of personal hygiene and conduct educational activities in this regard.

It needs to be remembered that testing swimming pool water quality for the content of combined chlorine (chloramines) should be connected not only with the control of free chlorine and redox potential, but also with the chemical oxygen demand (COD) and total organic carbon (TOC).

The higher doses of disinfectants in SP2 also influenced the other water quality parameters (Table 2). To compare, the average redox potential value in SP2 pool was $714 \mathrm{mV}$, while in SP1 it was $664 \mathrm{mV}$, in SP3 $634 \mathrm{mV}$ and in SP4 $628 \mathrm{mV}$; the average COD in SP2 was $0.53 \mathrm{mg} \mathrm{O} / \mathrm{L}$, while in SP1, SP3 and SP4 it was more than $1.50 \mathrm{mg} \mathrm{O}_{2} / \mathrm{L}$. The average content of TOC in SP2 was $0.72 \mathrm{mg} \mathrm{C/L,}$ while in SP1 $3.29 \mathrm{mg} \mathrm{C/L}$, in SP3 $7.12 \mathrm{mg} \mathrm{C/L}$ and in SP4 9.26 mg C/L. The other analyzed parameters did not differ markedly (turbidity was between $0.18 \div 0.20 \mathrm{NTU}$, nitrate $2.7 \div 3.5 \mathrm{mg} \mathrm{NO}_{3}^{-} / \mathrm{L}$, THM 0.040 $\div 0.041 \mathrm{mg} / \mathrm{L}$ ). The analysis of the complementary parameters also indicates a better quality of water in pools with a vertical hydraulic system (SP1 and SP2). 
Table 2. The overall quality of swimming pool water determined by the additional parameters.

\begin{tabular}{ccccc}
\hline Parameter, Units & SP1 & SP2 & SP3 & SP4 \\
\hline Redox potential, $\mathrm{mV}^{-} \mathrm{L}$ & 664 & 714 & 634 & 628 \\
Nitrate content, $\mathrm{mg} \mathrm{NO}_{3}{ }^{-\mathrm{L}}$ & 2.8 & 2.7 & 3.0 & 3.5 \\
Turbidity, $\mathrm{NTU}$ & 0.18 & 0.19 & 0.18 & 0.20 \\
Chemical oxygen demand-COD, $\mathrm{mg} \mathrm{O}_{2} / \mathrm{L}$ & 1.55 & 0.53 & 1.54 & 1.53 \\
Total trihalomethanes-THM, $\mathrm{mg} / \mathrm{L}$ & 0.040 & 0.040 & 0.040 & 0.041 \\
Total organic carbon-TOC, $\mathrm{mg} \mathrm{C} / \mathrm{L}$ & 3.29 & 0.72 & 7.12 & 9.26 \\
\hline
\end{tabular}

The results of the microbiological analysis of pool water sampled from pools SP1, SP2 and SP3 did not raise any objections. No presence of the cfu of the total number of microorganisms $\left(\right.$ at $36{ }^{\circ} \mathrm{C} \pm$ $2{ }^{\circ} \mathrm{C}$ after $48 \mathrm{~h}$ ), Escherichia coli and Pseudomonas aeruginosa was found in these pools, while in the water samples from SP4 pool, $2 \mathrm{cfu} / 100 \mathrm{~mL}$ of Escherichia coli were present. The water circulation system used in SP4 pool is not recommended for public swimming pools. The inflow in the short wall of the basin, the number of inlet nozzles and the outflow of water from the bottom do not comply with the requirements of a modern swimming pool. The high variability of the concentration of the tested parameters at various sampling points of this pool indicates the insufficient mixing of water and a worse overall sanitary condition of water.

\section{Summary and Conclusions}

The distribution of free and combined chlorine concentration was analyzed in four basins differing in seasonality of use and in the applied water flow systems. The parameters selected in the study are the most important, and easy to determine, chemical parameters that are used in the analysis of the health risk to people using swimming pools. The analysis of free chlorine concentrations in the characteristic points of the pools makes it possible to assess the antiseptic effect of the disinfectant, protecting against bacteriological contamination of water and the spread of pathogenic microorganisms. In turn, the concentration of combined chlorine determines the comfort and safety of swimming in terms of threat from DBP.

The type of hydraulic system undoubtedly influenced the cleanliness of the water. The flow time, location and distance between the inflow and outflow nozzle clearly contribute to the better quality of water in pools with a vertical hydraulic system. The results of analysis confirm the better efficiency of this kind of hydraulic system. The cooperation of the hydraulic system with the treatment and disinfection system guarantee that the quality of the pool water is safe for its users. The flow of water through the basin should not cause the "dead" zones that do not take part in the circulation. To avoid them, the flow of water through the basin should be as short as possible.

Variation in chlorine concentrations was observed in samples taken from various points in the same measurement series. The most uniform distribution of the concentration of both free and combined chlorine was observed in the middle point of swimming pools. However, at points near the corners and walls of swimming pools, the distribution of concentrations varied (the largest deviations from the average value).

According to Polish law, the concentration of combined chlorine in water sampled from the pool basin may not exceed $0.3 \mathrm{mg} \mathrm{Cl} / \mathrm{L}$. There was a variation in the combined chlorine content and non-compliance with the requirements in this matter in indoor pools. Very low concentrations of combined chlorine in the outdoor pool resulted from the use of high doses of disinfectant and maintaining higher than necessary concentrations of free chlorine.

In the case of recurring problems with maintaining adequate concentrations of free and combined chlorine, it is worth considering using at least two-stage disinfection. In addition to chlorine disinfection, alternative processes could be included: electrochemically generated mixed oxidants, ultraviolet irradiation (UV) and UV-based advanced oxidation processes (AOPs), such as $\mathrm{UV} / \mathrm{H}_{2} \mathrm{O}_{2}$, ozone $\left(\mathrm{O}_{3}\right)$ and ozone-based AOPs, such as $\mathrm{O}_{3} / \mathrm{H}_{2} \mathrm{O}_{2}$ and $\mathrm{O}_{3} / \mathrm{UV}$. 
This is an initial work on assessing the health safety of water in public pools. Determining the content of free chlorine and combined chlorine at various (but characteristic) points of pool basins can help to quickly assess the potential health risk to swimmers.

The results of the tests confirm the need for further, multi-parameter tests and observations in the field of chemical and bacteriological pollution distribution in pool waters and their impact on the assessment of pool water quality and health safety of swimmers and staff.

Based on the obtained test results, and in order to assess the degree of pool water pollution, the authors recommend collecting pool water samples from several characteristic points. The risk to the health of persons in a swimming pool should be assessed on the basis of the least favorable results.

Author Contributions: Conceptualization, J.W.-K. and A.L.-R.; methodology and resources, J.W.-K. and A.L.-R.; formal analysis, investigation, data curation J.W.-K. and A.L.-R.; writing-original draft preparation, J.W.-K. and A.L.-R.; writing-review, editing and visualization, J.W.-K., A.L.-R., and M.D.; supervision, M.D.; project administration J.W.-K.; funding acquisition, J.W.-K, A.L.-R., M.D. All authors have read and agreed to the published version of the manuscript.

Funding: This work and the APC were funded by Ministry of Science and Higher Education Republic of Poland within statutory funds and under the rector's habilitation grant of Silesian University of Technology No. 08/040/RGH19/0125, and by National Science Centre in Poland No. 2018/29/N/ST8/01352.

Conflicts of Interest: The authors declare no conflict of interest.

\section{References}

1. World Health Organization. Guidelines for Safe Recreational Water Environments; Swimming Pools and Similar Environments; WHO: Geneva, Switzerland, 2006; Volume 2, Available online: http://www.who.int/water_ sanitation_health/bathing/srwe2full.pdf (accessed on 22 March 2019).

2. Tang, H.L.; Ristau, R.J.; Xie, Y.F. Disinfection By-Products in Swimming Pool Water: Formation, Modeling, and Control; American Chemical Society: Washington, DC, USA, 2015; pp. 381-403. [CrossRef]

3. Tang, H.L.; Ristau, R.J.; Xie, Y.F.; Simard, S.; Tardif, R.; Rodriguez, M.J.; Catto, C.; Charest-Tardif, G.; Simard, S. Variability of Chlorination By-Product Occurrence in Water of Indoor and Outdoor Swimming Pools. Water Res. 2013, 47, 1763-1772. [CrossRef]

4. Chowdhury, S.; Alhooshani, K.; Karanfil, T. Disinfection Byproducts in Swimming Pool: Occurrences, Implications and Future Needs. Water Res. 2014, 53, 68-109. [CrossRef]

5. Tardif, R.; Rodriguez, M.; Catto, C.; Charest-Tardif, G.; Simard, S. Concentrations of Disinfection By-Products in Swimming Pool Following Modifications of the Water Treatment Process: An Exploratory Study. J. Environ. Sci. 2017, 58, 163-172. [CrossRef]

6. Lee, J.; Jun, M.J.; Lee, M.H.; Lee, M.H.; Eom, S.W.; Zoh, K.D. Production of Various Disinfection Byproducts in Indoor Swimming Pool Waters Treated with Different Disinfection Methods. Int. J. Hyg. Environ. Health 2010, 213, 465-474. [CrossRef]

7. Carter, R.A.A.; Joll, C.A. Occurrence and Formation of Disinfection By-Products in the Swimming Pool Environment: A Critical Review. J. Environ. Sci. 2017, 58, 19-50. [CrossRef] [PubMed]

8. Ilyas, H.; Masih, I.; van der Hoek, J. Disinfection Methods for Swimming Pool Water: Byproduct Formation and Control. Water 2018, 10, 797. [CrossRef]

9. Ilyas, H.; Masih, I.; van der Hoek, J. An Exploration of Disinfection By-Products Formation and Governing Factors in Chlorinated Swimming Pool Water. J. Water Health 2018, 16, 861-892. [CrossRef] [PubMed]

10. Orlov, V.; Zotkin, S.; Pelipenko, A. Mathematical Modelling of Water Exchange in Public Swimming Pools. IOP Conf. Ser. Mater. Sci. Eng. 2018, 365, 042016. [CrossRef]

11. Gomà, A.; de Lluis, R.; Roca-Ferrer, J.; Lafuente, J.; Picado, C. Respiratory, Ocular and Skin Health in Recreational and Competitive Swimmers: Beneficial Effect of a New Method to Reduce Chlorine Oxidant Derivatives. Environ. Res. 2017, 152, 315-321. [CrossRef]

12. Li, J.H.; Wang, Z.H.; Zhu, X.J.; Deng, Z.H.; Cai, C.X.; Qiu, L.Q.; Chen, W.; Lin, Y.J. Health Effects from Swimming Training in Chlorinated Pools and the Corresponding Metabolic Stress Pathways. PLoS ONE 2015, 10, e0119241. [CrossRef]

13. Pándics, T.; Hofer, Á.; Dura, G.; Vargha, M.; Szigeti, T.; Tóth, E. Health Risk of Swimming Pool Disinfection By-Products: A Regulatory Perspective. J. Water Health 2018, 16, 947-957. [CrossRef] [PubMed] 
14. Van Veldhoven, K.; Keski-Rahkonen, P.; Barupal, D.K.; Villanueva, C.M.; Font-Ribera, L.; Scalbert, A.; Bodinier, B.; Grimalt, J.O.; Zwiener, C.; Vlaanderen, J.; et al. Effects of Exposure to Water Disinfection By-Products in a Swimming Pool: A Metabolome-Wide Association Study. Environ. Int. 2018, 111, 60-70. [CrossRef] [PubMed]

15. De Laat, J.; Feng, W.; Freyfer, D.A.; Dossier-Berne, F. Concentration Levels of Urea in Swimming Pool Water and Reactivity of Chlorine with Urea. Water Res. 2011, 45, 1139-1146. [CrossRef] [PubMed]

16. Teo, T.L.L.; Coleman, H.M.; Khan, S.J. Chemical Contaminants in Swimming Pools: Occurrence, Implications and Control. Environ. Int. 2015, 76, 16-31. [CrossRef] [PubMed]

17. Gallè, F.; Dallolio, L.; Marotta, M.; Raggi, A.; Di Onofrio, V.; Liguori, G.; Toni, F.; Leoni, E. Health-Related Behaviors in Swimming Pool Users: Influence of Knowledge of Regulations and Awareness of Health Risks. Int. J. Environ. Res. Public Health 2016, 13, 513. [CrossRef]

18. Liguori, G.; Capelli, G.; Carraro, E.; Di Rosa, E.; Fabiani, L.; Leoni, E.; Marensi, L.; Napoli, C.; Pasquarella, C.; Romano Spica, V.; et al. A New Checklist for Swimming Pools Evaluation: A Pilot Study. Microchem. J. 2014, 112, 181-185. [CrossRef]

19. Zarzoso, M.; Llana, S. Potential Negative Effects of Chlorinated Swimming Pool Attendance on Heath of Swimmers and Associated Staff. Biol. Sport 2010, 27, 233-240. [CrossRef]

20. Barna, Z.; Kádár, M. The Risk of Contracting Infectious Diseases in Public Swimming Pools. A Review. Annali dell'Istituto Superiore di Sanità 2012, 48, 374-386. [CrossRef]

21. Cloteaux, A.; Gérardin, F.; Midoux, N. Influence of Swimming Pool Design on Hydraulic Behavior: A Numerical and Experimental Study. Engineering 2013, 05, 511-524. [CrossRef]

22. Saunus, C. Planug von Schwimmbadern (Planning of Swimming Pools); Krammer Verlag Dusseldorf AG: Dusseldorf, Germany, 1998.

23. Wei, X.; Li, J.; Hou, S.; Xu, C.; Zhang, H.; Atwill, E.; Li, X.; Yang, Z.; Chen, S. Assessment of Microbiological Safety of Water in Public Swimming Pools in Guangzhou, China. Int. J. Environ. Res. Public Health 2018, 15, 1416. [CrossRef]

24. Guida, M.; Di Onofrio, V.; Gallè, F.; Gesuele, R.; Valeriani, F.; Liguori, R.; Romano Spica, V.; Liguori, G. Pseudomonas Aeruginosa in Swimming Pool Water: Evidences and Perspectives for a New Control Strategy. Int. J. Environ. Res. Public Health 2016, 13, 919. [CrossRef] [PubMed]

25. Aboulfotoh Hashish, N.M.; Gawad Abbass, A.A.; Khamis Amine, A.E. Pseudomonas Aeruginosa in Swimming Pools. Cogent Environ. Sci. 2017, 3. [CrossRef]

26. Wyczarska-Kokot, J.; Lempart, A.; Dudziak, M. Chlorine Contamination in Different Points of Pool—Risk Analysis for Bathers' Health. Ecol. Chem. Eng. A 2017, 24, 217-226. [CrossRef]

27. Wyczarska-Kokot, J. The Problem of Chloramines in Swimming Pool Water-Technological Research Experience. Desalin. Water Treat. 2018, 134, 7-14. [CrossRef]

28. Lempart, A.; Kudlek, E.; Dudziak, M. Determination of Micropollutants in Water Samples from Swimming Pool Systems. Water 2018, 10, 1083. [CrossRef]

29. DIN 19643. Water Treatment for Swimming and Bathing Pools; Beuth-Verlag: Berlin/Düsseldorf, Germany, 2012. (In German)

30. RCL. Decree of the Health Minister on the Requirements for Water in Swimming Pools; Dz. U. of 2015, Item 2016; RCL: Warsaw, Poland, 2015. Available online: http://isap.sejm.gov.pl/DetailsServlet?id=WDU20150002016 (accessed on 22 March 2019). (In Polish)

(C) 2020 by the authors. Licensee MDPI, Basel, Switzerland. This article is an open access article distributed under the terms and conditions of the Creative Commons Attribution (CC BY) license (http://creativecommons.org/licenses/by/4.0/). 